\title{
Ensaiar a si mesmo: autorretrato e multidão em News from home e Lost book found
}

\author{
Tatiana Hora*
}

Resumo: Os ensaios Lost book found (1996), de Jem Cohen, e News from home (1977), de Chantal Akerman narram experiências em Nova Iorque que intercalam o eu e a multidão. Eles aderem à subjetiva indireta livre para romper com os limites entre "as imagens que a câmera vê" (objetivas) e "as imagens que a personagem vê" (subjetivas) e desestabilizam a instância narrativa dando abertura a outras experiências da cidade.

Palavras-chave: autorretrato; ensaio; agenciamentos coletivos de enunciação; subjetiva indireta livre.

Resumen: Los ensayos Lost book found (1996), de Jem Cohen, y News from home (1977), de Chantal Akerman, relatan experiencias en Nueva York que intercalan el yo y la multitud. Ambos se adhieren a la subjetividad indirecta para romper los límites entre "las imágenes que la cámara ve" (objetivas) y "las imágenes que el personaje ve" (subjetivas), y desestabilizan la instancia narrativa dando apertura a otras experiencias de la ciudad.

Palabras clave: autorretrato; ensayo; agenciamientos colectivos de enunciación; imagen subjetiva indirecta libre.

Abstract: The essays Lost book found (1996), by Jem Cohen, and News from home (1977), by Chantal Akerman narrate experiences in New York that intercalate the self and the crowd. They adhere to the free indirect subjective to break the boundaries between "the images that the camera sees" (objective) and "the images that the character sees" (subjective), and destabilize the narrative instance giving way to other city experiences.

Keywords: self-portrait; essay; collective disposals of enunciation.

Résumé: Les essais Lost book found (1996), de Jem Cohen, et News from home (1977), de Chantal Akerman, racontent des expériences qui se passent à New York, dans lesquelles s'entrelacent le moi et la foule. Ils s'attachent au plan subjectif indirect libre pour rompre avec "les images que la caméra ne voit pas"(objectives) et "les images que le personnage voit"(subjectives), et déstabilisent l'instance narrative en permettant d'autres expériences de la ville.

Mots-clés: autoportrait; essai; agencement collectif d'énonciation.

\footnotetext{
* Doutoranda. Universidade Federal de Minas Gerais - UFMG, Dept. de Comunicação Social, Programa de Pós-Graduação em Comunicação Social. 31270-901, Belo Horizonte, Brasil. E-mail: tati_hora@hotmail.com
}

Submissão do artigo: 30 de dezembro de 2015. Notificação de aceitação: 23 de fevereiro de 2016. 
Ruas percorridas por automóveis e transeuntes, enquadradas por planos geométricos, ${ }^{1}$ que valorizam o equilíbrio das linhas e formas da arquitetura da cidade. Em News from home (1977), Chantal Akerman ${ }^{2}$ apresenta um olhar entre a objetividade da arquitetura de Nova Iorque e a subjetividade da experiência da estrangeira que nela reside temporariamente. A voz over da cineasta lê as cartas escritas por sua mãe perguntando por notícias de sua estadia em Nova Iorque, e tudo o que vemos é o exterior: a ensaísta escreve sobre si com imagens através do espaço da rua, como se houvesse uma interseção entre o seu eu e aquela cidade. Um "eu" que é uma condição passageira, como vemos ao final do filme, num plano feito do ponto de vista de um navio que vai embora de Nova Iorque. Diversos personagens percorrem o espaço sem sabermos de onde eles vêm, muito menos para onde vão, não nos deixando nenhuma história, nem sequer um rastro além de suas aparições furtivas. No entanto, é através do relativo apagamento da cineasta nas marcas de enunciação que esses anônimos adquirem uma maior força dentro do filme, pois assumem uma presença própria que nos remete a outras experiências vividas naquele espaço.

Lost book found (1996), de Jem Cohen, traz planos do ponto de vista do alto de um arranha-céu, e ouvimos o narrador-personagem comentar sobre a paisagem que vê e também sobre aquilo que não pode enxergar, enquanto perscruta as janelas do edifício em frente, mostrando pessoas percorrendo seus apartamentos na forma de vultos. A montagem alterna entre os planos do ponto de vista do arranha-céu e imagens a partir de carrinhos de ambulantes, enquanto o narrador-personagem conta: "eu descobri que, por ficar atrás do carrinho, vendendo, eu havia construído uma parede e uma janela, de onde podia observar o que acontecia na rua, naquele longo corredor de empresários e passantes". Jem Cohen, nascido no Afeganistão, trabalhou como ambulante em Nova Iorque, o que nos remete a uma possível autobiografia, mas não fica

1. Segundo Deleuze (1983), o quadro geométrico é aquele onde o espaço é composto por linhas paralelas e diagonais de acordo com o equilíbrio das formas, apresentando um movimento invariável. Se, de acordo com o autor, o enquadramento é limitação, os limites do quadro geométrico são definidos por ele como matemáticos, ou seja, são os limites do quadro que impõem as condições sobre os corpos que o percorrem.

2. Segundo Ivone Margulies (1996), durante sua estadia em Nova Iorque de 1971 a 1972, a cineasta Chantal Akerman entrou em contato com o cinema experimental de Andy Warhol e os filmes-diários de Jonas Mekas. Lembremos que Warhol realizou obras como Empire State Building (1964), um plano-sequência de pouco mais de oito horas do edifício homônimo em Nova Iorque da noite até o amanhecer, e Sleep (1963), que mostra mais de seis horas de sono de um rapaz, filmes que apresentam um aniquilamento da subjetividade e uma pretensão de capturar o cotidiano no seu transcorrer pela reprodução técnica. Já Jonas Mekas, num ensaio como Lost, lost, lost (1976), apresenta um diário íntimo com imagens fragmentárias da sua experiência enquanto exilado da Lituânia residente em Nova Iorque. Entre Warhol e Mekas, Chantal parece herdar o apagamento da subjetividade de Warhol e as inflexões ensaístas com tom autobiográfico de Mekas. 
claro onde termina a ficção e começa o documentário, onde finda a vida e se inicia a encenação.

Lost book found apresenta a história do ambulante que teria comprado um livro de um misterioso "pescador de objetos", que havia pescado o livro na vala do metrô. O cineasta elabora um ensaio que cria ficções a partir de imagens do cotidiano de Nova Iorque, chegando a confundir não só os limites entre o objetivo e o subjetivo, promovendo também uma dialética entre o real e o imaginário ao elaborar a atmosfera onírica sobre a iminência de uma chuva de moedas em Nova Iorque a partir de flagrantes documentais. Segundo Cláudia Mesquita, "Jem Cohen conta que, à época em que realizou o filme, interessava-lhe enfrentar a ideia inspiradora de que 'o mundo é feito de narrativas, um milhão delas; algumas invisíveis, algumas esquecidas, algumas que desapareceram antes mesmo de serem contadas" (2006; 143). As múltiplas narrativas possíveis que habitam as ruas interessam ao narrador-personagem de tal modo que desestabilizam a instância narrativa, e assim o filme parte de uma experiência que se conecta a infinitas outras experiências possíveis na cidade.

Vestígios? São as vidas que passaram por aí, os corpos, as palavras, as narrativas, todo um emaranhado de encontros tão intensivamente vividos quanto rapidamente perdidos. Filmada, a cidade se torna texto, hipertexto, e mesmo, simultaneamente, coletânea de todas as histórias possíveis nas cidades e léxico de todas as palavras trocadas. (Comolli, 2008: 180).

\section{Ensaio e autorretrato}

Os ensaios News from home e Lost book found apresentam subjetividades instáveis, multifacetadas, proteiformes. Lembremos que, no ensaio, "o sujeito está em movimento, em metamorfose, em explosões, ele pode tomar diversas faces, elas também contraditórias" 3 (Neyrat, 2004: 159).

Em News from home, a leitora das cartas, Chantal, fala de si convivendo com a voz da autora das cartas, sua mãe, e se oculta sob a austeridade de planos aparentemente impessoais. Já em Lost book found, a narração do ex-vendedor ambulante convive com a instabilidade da memória empreendida pela voz do livro. Os narradores se esboçam na relação com os outros personagens com os quais se deparam nas andanças por Nova Iorque: sejam os ambulantes de Lost book found, ou os anônimos no metrô e nas ruas encarando a câmera em News from home. Esses filmes seguem a lição de Montaigne, que, segundo Starobinski, elaborava ensaios como registros da sua vida, "mas os ensaios de

3. No original : "Le sujet y est en mouvement, en métamorphose, éclate, il peut prendre plusiers visages, eux aussi contradictoires." 
sua vida, excedendo sua existência individual, concernem à vida dos outros, que ele não pode separar da sua" (Starobinski, 2011: 8).

Segundo Cyril Neyrat (2004), se o ensaísta é a matéria da sua obra, o ensaísmo está mais para os autorretratos do que para as autobiografias. Mas, antes de chegar à noção de autorretrato, vamos primeiramente apresentar o conceito de autobiografia segundo a conceção pragmática de Phillipe Lejeune (2008), noção problematizada por Paul de Man (1979) no ensaio Autobiografia como desfiguração.

Primeiramente, saber se os ensaios News from home e Lost book found são autobiografias envolve parâmetros complexos. Num primeiro momento, Phillipe Lejeune (2008) define a autobiografia como um texto onde há identidade entre autor, narrador e personagem. Em seguida, a partir de narrativas que tencionam essa relação e deslocam o problema da primeira pessoa como aspeto central (na autobiografia nem sempre o narrador diz "eu"), ele chega ao conceito de pacto autobiográfico. Lejeune (2008) conceitua a autobiografia com base no contrato estabelecido entre escritor e leitor, ou, em termos cinematográficos, entre cineasta e espectador.

News from home, por exemplo, apresenta a leitura de cartas em voz over dirigidas a Chantal, mesmo nome da diretora, o que nos levaria a concluir, tendo como norte o conceito de Lejeune (2008), que se trata de uma autobiografia. No entanto, a cineasta jamais fala de si nem da sua relação com a cidade de Nova Iorque, todavia a sua experiência da cidade é narrada através de planos com uma duração dilatada, que acolhem a banalidade cotidiana. Como afirma Bergstrom (2004), "de todo modo, neste filme como em todos os outros, Chantal Akerman utiliza apenas elementos autobiográficos cuidadosamente delineados. Sua vida não é um livro aberto e estamos bem longe do cinema verdade". 4

Já em Lost book found nós não conhecemos o nome do narrador que trabalhou como vendedor ambulante nas ruas de Nova Iorque, embora saibamos por informações exteriores ao filme que o cineasta Jem Cohen exerceu essa atividade na metrópole, o que nos leva a suspeitar que a obra apresente elementos autobiográficos. Segundo Philippe Lejeune (2008), alguns textos ficcionais narram eventos que são conhecidos como integrantes da trajetória de vida do autor, mas isso não leva a caracterizar tais textos como autobiografias, e sim como romances autobiográficos, posto que o autor não assume a identidade entre autor e personagem, não conformando o pacto. Lost book found está circunscrito ao grau zero do pacto, ou à ausência de contrato, como afirma

4. No original: "Néanmoins, dans ce film comme dans tous les autres, Chantal Akerman n'utilise que des éléments autobiographiques soigneusement délimités. Sa vie n'est pas un livre ouvert et l'on est bien loin du cinéma-vérité.' 
Lejeune acerca de obras literárias em que "não apenas o personagem não tem nome, mas o autor não firma nenhum pacto - nem autobiográfico, nem romanesco. A indeterminação é total.” (Lejeune, 2008: 29).

Como podemos perceber, os ensaios News from home e Lost book found estão bem longe de compor autobiografias no sentido clássico do termo, ou seja, não apresentam uma identidade plena entre autor, narrador e protagonista, nem trazem à tona confissões acerca de suas biografias que poderiam aludir a uma continuidade coerente de suas trajetórias de vida.

Partindo da contestação do conceito de autobiografia de Lejeune, Paul De Man (1979) afirma que, apesar de Lejeune deslocar a noção de autobiografia do problema do referente, ou seja, definindo-a não a partir da verdade dos relatos, mas sim da relação contratual estabelecida com o leitor através do nome próprio, ele acaba por não superar a questão do referente. De Man argumenta que o sujeito contratual finda por se tornar uma autoridade transcendental que permite ao leitor julgá-lo por suas histórias, isto é, a antiga estrutura especular teria sido desarticulada, mas não suplantada.

Segundo Paul De Man (1979), a autobiografia não é um gênero, mas sim uma figura de leitura que, de certo modo, é encontrável em todos os textos, pois o momento autobiográfico consistiria na substituição reflexiva mútua entre os dois sujeitos envolvidos no processo de leitura, o autor e o leitor (ou o cineasta e o espectador). Ainda de acordo com De Man (1979), se todo texto é autobiográfico, ao mesmo tempo nenhum pode ser, pois não é possível o autoconhecimento pleno, nem a totalização do eu.

De Man (1979) afirma que a figura de linguagem da autobiografia é a prosopopeia: se a prosopopeia quer dizer personificação, ou seja, atribuir qualidades humanas a seres inanimados, a autobiografia consiste em dar voz ou face através da linguagem. A autobiografia envolve os processos de figurar e desfigurar. Nos filmes News from home e Lost book found, a dialética entre figuração e desfiguração acontece a partir da tensão entre narrador e imagens, isto é, dos obstáculos entre o que é dito e o que é visto, do descentramento da instância narrativa e da dualidade entre corpo e descorporalização. Os dois ensaios são narrados por acúsmetros, tal como na definição de Michel Chion (1999), pois são personagens invisíveis de quem conhecemos a voz, mas não vemos o seu corpo. E são tipos específicos de acúsmetro, caracterizados pela voz-eu, ou a voz que narra a sua própria experiência.

Em News from home, quando Chantal toma corpo no filme, esse corpo é um reflexo na janela da porta do metrô, uma imagem num quadro dentro do quadro. Mas essa figura não surge num espelho límpido, onde podemos ver as suas formas com nitidez. Ao contrário, a efígie aparece num vidro embaçado 
da porta de um metrô, onde mal podemos ver o seu semblante. O corpo da cineasta Chantal surge enquanto uma imagem entre outras imagens. Se, como afirma Michel Chion (1999), a voz-eu no cinema é, em geral, gravada em estúdio com isolamento sonoro que garante a aparência de "descorporalização" e a identificação do espectador ao ouvi-la como se fosse a sua própria voz, já em News from home a voz em diversas cenas é suplantada pelos ruídos de carros e passantes, numa ambivalência entre ausência de corpo e corporeidade devido à inserção da voz na circunstância do real. Além disso, a voz-eu em News from home sequer fala de si, mas tão somente lê num timbre monocórdio as cartas que a mãe de Chantal escreveu, numa duplicidade entre a leitora das cartas que é narradora do filme, e a autora das cartas que também é narradora.

Nas cartas, a mãe reclama de longos períodos sem receber nenhuma correspondência da filha, ressalta que os endereços de remetente estavam sempre mudando, conta que vai viajar com o marido, pede para ela visitar parentes no Bronx que conhecem cineastas e podem ajudá-la a conseguir emprego na indústria do cinema; e relata pequenos casos de família, a exemplo da prova de Sylviane e do divórcio de Jean-Pierre e Lydie, tudo lido pela voz indiferente de Chantal.

Nessa sequência, enquanto a mãe narra acontecimentos de sua vida e da família, o ensaio nos apresenta planos banais de um estacionamento e de pessoas anônimas sentadas sozinhas na calçada ou conversando em grupos nas ruas, de quem sequer nos aproximamos. Se News from home pode ser considerado um filme-epístola, certamente é feito com correspondências inscritas em imagens que nada nos contam. Suas imagens são como cartas em branco, se procurarmos nelas ações. A disjunção entre o universo das cartas com seus casos narrados, e o âmbito da leitura das cartas, que convive lado a lado com imagens não-narrativas, é reforçada pelas pausas, silêncios e pela aridez dos planos, de modo a colocar um obstáculo entre a leitura das cartas e a sua escrita; segundo Ivone Margulies, essa obstrução é comum na obra da cineasta.

A mise-en-scène de Akerman alternadamente convoca um discurso direto para a sua personagem e coloca aspas no seu discurso com a inserção de vazios, longos silêncios e uma frontalidade enviesada. Uma deliberada distribuição estranha dos textos desestabiliza uma confortável associação entre a fala e a escrita, o roteiro e o diálogo. A fala nunca absorve inteiramente o discurso; o sentido de autoridade nunca se dissolve completamente numa terceira pessoa narrativa transparente. ${ }^{5}$ (Margulies, 1996: 149).

5. Akerman's mise en scène alternately claims a direct discourse for her character and brackets his speech through blank delivery, long silences, and a skewed frontality. A deliberately awkward distribution of text disallows a comfortable fit between writing and speech, script and dialogue. Speech never entirely absorbs discourse; the sense of authorship never completely dissolves into a transparent third-person narrative. 
Já em Lost book found, a voz do livro assume a forma de uma alegoria do texto urbano escrito por múltiplos autores do livro-cidade, assim, o exambulante se desfigura para então se figurar ao se agenciar com a coletividade que habita as ruas. Numa cena, a voz-eu do narrador conta que costumava caminhar bastante, até que decidiu comprar um carro. Aos poucos, a sua voz vai sumindo, enquanto vemos a janela de um carro em movimento embaçada pela chuva. Outra voz começa a dizer coisas ininteligíveis e, em seguida, diversos títulos como: "Mercúrio"; depois, a voz do livo pronuncia coordenadas espaços-temporais como: "215, Oeste, Rua 34, 9 e 12 am. Broadway Star Neile”, entre outras. A voz do livro profere também títulos relacionados a imagens como se fossem quadros em movimento, a exemplo de quando diz: "O arquivo" sobre o plano de um homem que dorme no chão enquanto um vulto passa rapidamente; ou: "O homem que dorme", referente a um homem dormindo na rua entre muitos papéis esvoaçantes; e: "Vitória", alusivo a uma bandeirinha dos Estados Unidos. Os enquadramentos apresentam uma indeterminação do ponto de vista (quem vê essas imagens?), pois não há elementos que as vinculem precisamente a um personagem, já que a "voz do livro" não exibe a definição e o timbre de uma voz-eu e as palavras são dificilmente compreendidas.

Segundo Raymond Bellour, no cinema a autobiografia "se torna fragmentária, limitada, dissociada, incerta - influenciada por essa forma superior de dissociação que nasce dos disfarces da ficção" 6 (Bellour, 2009: 293). E é por isso que o autor, referindo-se ao cinema, se afasta do conceito de autobiografia (ele parte da contestação do conceito de Lejeune) e recorre à noção de autorretrato. Em vez de evocar a experiência pelas palavras, o autorretrato promove uma escavação em busca de imagens. Entretanto, o autor de autorretratos é comparado a Narciso por Raymond Bellour: ao se deparar com sua imagem refletida na água, ele mergulha no rio e acaba se afogando e "é verdadeiramente afogando a si mesmo que Narciso se constrói como autorretrato" (Bellour, 2009: 308).

Segundo Cyril Neyrat (2004), o ensaio é feito da forma do autorretrato composto de instantâneos esparsos, não da narrativa autobiográfica plena e o sujeito do ensaio se situa abaixo do cartesiano, pois está imerso numa oscilação de fluxo e refluxo entre sujeito e mundo. Para a autora, o ensaísta está entre Narciso e Proteu, centrado em si mesmo e lançado ao mundo, em constante transformação. É nisto que se aproximam as definições de Bellour (2009) e Neyrat (2004) de autorretrato, e aquela de "autobiografia como desfigura-

6. No original: "Se vuelve fragmentaria, limitada, disociada, incierta - obsesionada con esta forma superior de disociación que nace de los disfraces de la ficción." 
ção", elaborada por De Man (979), em suas críticas à noção de autobiografia de Lejeune: a noção de pacto autobiográfico apresenta uma multiplicidade de possibilidades de textos autobiográficos (da coincidência entre narrador, personagem e autor à problematização dessas relações pelas obras), mas sempre mantém intacto o sujeito, com nome ou sem nome, falando abertamente de si ou não, e esses autores propõem desestabilizar o próprio sujeito autobiográfico. Nos ensaios Lost book found e News from home importa menos o pacto autobiográfico entre cineasta e espectador enquanto identidades fixas, do que a abertura da forma para outras experiências que habitam e constituem a cidade.

Em certo momento de Lost book found, o ex-vendedor ambulante conta que, a medida que se tornava invisível, começava a enxergar coisas que antes eram invisíveis para ele. Durante o processo de rememoração, o narrador se encontra entre imagens, deparando-se com lacunas e flashes, construindo um relato entre o esquecer e o lembrar como se fossem duas atividades indissociáveis. Já em News from home, os planos frontais e fixos de longa duração promovem uma aparente "não-mediação", como se o dispositivo cinematográfico acolhesse o tempo em seu transcorrer. Nesses dois ensaios, o sujeito autobiográfico é colocado em questão através da imbricação entre sujeito e mundo, entre o narrador e as infinitas experiências da cidade, e entre o "eu" e o "outro", imersos na multidão.

\section{Eu é outro}

Os ensaios News from home e Lost book found vão muito além do "falar sobre si" em seus autorretratos elaborados no espaço da cidade, não apenas porque se afastam de uma narrativa autobiográfica confessional mas, também e, principalmente, porque empregam recursos estilísticos que dão a ver uma rutura com uma subjetividade estável. Não se trata de um "eu" que explora a sua trajetória de vida, nem de um "eu" que encara o "outro" como objeto. News from home e Lost book found produzem, cada um ao seu modo, um pacto com a experiência coletiva urbana.

Ao abordar a narração clássica, Deleuze (2005) a define sob o conceito de "regime orgânico" e afirma que "por convenção, chama-se objetivo o que a câmera 'vê', e subjetivo o que a personagem 'vê'" (Deleuze, 2005: 179-180); isso resulta numa dicotomia entre imagens objetivas e subjetivas no cinema, como também numa identidade constante do tipo $\mathrm{Eu}=\mathrm{Eu}$. Tal convenção da narrativa clássica é definida por Pasolini como cinema de prosa, que o cineasta italiano opõe ao cinema de poesia, ou ao cinema moderno por excelência. Segundo Pasolini (1982), enquanto o cinema clássico traça uma clara distinção entre o mundo objetivo e a subjetividade dos personagens, oferecendo pistas 
bastante didáticas de que "trata-se de uma subjetividade" e não do "real", o cinema de poesia confunde os limites entre objetividade e subjetividade ao aderir à subjetiva indireta livre. No cinema de poesia defendido por Pasolini, o autor não fala sobre uma personagem, mas segundo sua língua, isto é, incorpora na escritura da obra a perceção de mundo da personagem através de princípios formais e estilísticos.

De acordo com Deleuze (2005), diferente da narração do regime orgânico, na narração do regime cristalino não há um $e u$ que se identifica com a câmera e filma o outro como objeto. A identidade $\mathrm{Eu}=\mathrm{Outro}$, segundo Deleuze, referese à infinita capacidade de metamorfose do cineasta e dos sujeitos filmados, de modo que ambos se envolvem num devir.

Ao tratar dos filmes de Jean Rouch e de Pierre Perrault, Deleuze (2005) alega que o cinema direto ${ }^{7}$ que envereda pelas potências do falso apresenta personagens que vivem o antes e o depois na encenação, que se transformam e fabulam a si mesmos para além do real e do fictício, cuja verdade é essa mudança e essa interpretação que transcorre diante da câmera. Deste modo, a subjetividade, não mais centrada, não mais fixa, não mais constante, migra para a coletividade, transmuta do $\mathrm{Eu}=\mathrm{Eu}$ para o $\mathrm{Eu}=\mathrm{Outro}$, e, portanto, "a personagem está sempre se tornando outra, e não é mais separável desse devir que se confunde com um povo" (Deleuze, 2005: 185). Assim sendo, as personagens fazem o discurso da África enquanto Jean Rouch realiza o seu discurso indireto livre em Moi, un noir, enquanto as personagens de Perrault elaboram o discurso do Quebec em Pour la suite du monde.

Nos ensaios Lost book found e News from home o coletivo não é apenas o objeto que está fora e que encanta o ensaísta, mas se incrusta na própria forma fílmica de modo a desestabilizar a identidade da câmera Eu=eu e convertê-la em Eu=outro. Lembremos da literatura menor de Kafka, tal como lida por Deleuze e Guattari (1977): uma forma literária que, diferente da grande literatura, que apresenta o individual tendo como pano de fundo o contexto histórico, vincula imediatamente o individual ao político. Da relação intrínseca entre o individual e o político presente na literatura menor resultam enunciados completamente contaminados pelo político, de modo que não há enunciações individuais, mas sim enunciações coletivas. Assim, na literatura menor não há sujeito, mas sim agenciamentos coletivos de enunciação. Para Deleuze e

7. O cinema direto nasce por volta do final dos anos 50, com a criação dos novos aparelhos portáteis de gravação de som e imagem, e, em seu primeiro momento, "acredita-se numa posição ética centrada no recuo do cineasta em seu corpo a corpo com o mundo" (Ramos, 2008: 269), sendo exemplar o filme Primary (1960), de Robert Drew. Num segundo momento, um filme como Crônica de um verão (1960), de Jean Rouch e Edgar Morin, revela uma modalidade do cinema direto que prefere explicitar a intervenção do cineasta no mundo e a encenação dos personagens no documentário, sendo chamado também de cinema verdade. 
Guattari (1977), não há um sujeito por trás do enunciado, assim como não há um sujeito que emana do enunciado ${ }^{8}$. Haveria, antes, uma função geral que promove um agenciamento polívoco, de múltiplas vozes e sentidos, da qual o indivíduo é uma parte e a coletividade outra parte, formando partes que se relacionam numa engrenagem. Segundo Deleuze e Guattari, a letra K em Kafka não designa nem um narrador nem um personagem, mas sim um agenciamento maquínico, um agente coletivo.

Assim como não se trata de Kafka, nos filmes que estudamos não é Chantal, a quem se dirigem as cartas de News from home, nem o personagem sem nome de Lost book found que estão por detrás do enunciado. Em termos de montagem, voz e enquadramento executados nestes filmes, é possível perceber a instabilidade da subjetividade frente aos agenciamentos coletivos de enunciação.

Não estamos falando de identificação, mas de agenciar. Segundo Deleuze e Pernet (1998), agenciar é estar no meio, é ser submerso na linha de encontro entre o mundo interior e o mundo exterior, e se absorver na corrente comum. Agenciar não é imitar o outro nem se identificar, mas produzir algo entre mim e o outro, o que nos leva a um devir, em que ambos não continuam sendo os mesmos. Como em News from home, pois a leitora das cartas submerge na multidão e nos olhares. Ou em Lost book found, em que o ex-ambulante, do ponto de vista "de baixo", 9 vive o corpo a corpo na deriva pela cidade. $\mathrm{O}$ agenciamento como co-funcionamento: "nem identificação nem distância, nem proximidade nem afastamento, pois, em todos estes casos, se é levado a falar por, ou no lugar de... Ao contrário, é preciso falar com, escrever com. Com o mundo, com uma porção de mundo, com pessoas" (Deleuze e Pernet, 1998: 43).

Lost book found e News from home recorrem à subjetiva indireta livre e dão a ver, portanto, realidades e subjetividades instáveis e narradores proteiformes, multifacetados. São narradores mutantes, que narram a experiência em constante transformação. Se o devir é um infinito tornar-se que nunca chega a uma identidade acabada, que não cabe na forma do modelo, e implica um encontro, ou núpcias, entre solidões, trata-se de "achar, encontrar, roubar, ao invés de regular, reconhecer e julgar. Pois reconhecer é o contrário do encontro"

8. Ao falar em "enunciado", é preciso enfatizar que estamos num âmbito diferente da literatura, pois estamos abordando o cinema. Diferente de Metz, que assimilava a imagem cinematográfica a um enunciado, Deleuze (2005) se desfaz das amarras do paradigma linguístico, e afirma que a imagem não é um enunciado, mas sim enunciável. Segundo Deleuze (2005: 43), a língua existe em relação a uma matéria não-linguística, e "é por isso que os enunciados e as narrações não são um dado das imagens aparentes, mas uma consequência que resulta dessa reação. A narração está fundada na própria imagem, mas não é dada”.

9. Ou, como diria Cláudia Mesquita (2006), Lost book found assume um ponto de vista "ao rés do chão". 
(Deleuze e Pernet, 1998: 8). Segundo Deleuze, o devir pode ser expresso no estilo, sendo o estilo considerado como um agenciamento de enunciação, ou, conforme sua síntese, trata-se de "conseguir gaguejar em sua própria língua (...)" (Deleuze, 1998: 4). O autor cita como exemplos de "gagos usando sua linguagem" o cineasta Godard e o escritor Kafka, entre outros.

Mas não é disso mesmo que é feito o ensaio, desse gaguejar em sua própria linguagem? Experimentar a linguagem cinematográfica, testar as fronteiras entre os domínios da ficção e do documentário, através do ensaísta que ensaia a si mesmo nos encontros que promove com os personagens e o mundo. Numa sequência de Lost book found, o narrador-personagem parece nos confessar a sua forma inacabada e a incerteza do assunto do filme. O narrador afirma que as listas do livro perdido permaneceram sendo ecoadas pela sua memória, com "certos lugares, coisas, e incidentes que parecem se encaixar como palavras cruzadas". Um plano em câmera baixa faz travellings e atenta para uma sacola rodopiando ao sabor do vento numa calçada, enquanto ouvimos a voz do narrador afirmar: "Com uma forma que sempre muda, cujo assunto eu nunca tive certeza em primeiro lugar".

Numa passagem de Lost book found, vemos um cartão onde está escrito "A lifetime income opportunity" 10 - em seguida, um pequeno bilhete com letras escritas à mão dizendo "To Mom, may you get lots of Money/ Love, Kisha". ${ }^{11}$ Então um travelling segue um homem adentrando uma passagem subterrânea numa calçada, até que ele fecha as portas. Uma superposição de imagens nos leva a um travelling que avança na direção da escada que conduz a uma estação no subsolo, por onde desce um casal. Em contra-plongée, a imagem apresenta um outdoor com o rosto de uma mulher sob a penumbra da noite, e uma voz num cassino diz: "Eu lhe contarei tudo, tenho uma cidade subterrânea aqui", e vemos um misterioso homem de chapéu, de costas, descendo uma escada rolante que leva a uma estação de trens. Bilhetes que remetem a histórias que não conhecemos, passagens enigmáticas no espaço da cidade, imagens da metrópole desconhecidas por nós. Lost book found não atenta apenas para o que antes era invisível aos olhos do narrador, mas também aponta para o que ainda não é visível no ensaio, para os espaços da cidade que o filme não consegue alcançar, o que está no fora de campo, e faz alusão a tantas narrativas que não foram contadas e que nos deixam apenas pistas, rastros, pegadas.

É por isso que o narrador-personagem nos pergunta quem escreveu o livro perdido, e em seguida apresenta uma série de retratos de anônimos. O exambulante conta suas histórias mostrando imagens de outros ambulantes como

10. Uma oportunidade de renda vitalícia.

11. Para a mamãe, você pode conseguir muito dinheiro. Com amor, Kisha. 
se o narrador se agenciasse com eles. O ensaio mostra imagens de pessoas dormindo num trem como se o narrador também fosse um deles, quando conta que pegava o trem para ir ao trabalho, e por trabalhar num escritório aos poucos foi perdendo contato com a cidade.

Os enquadramentos "com o olhar para baixo" em Lost book found apresentam muitas imagens de vestígios da cidade, como alguém varrendo o chão, papeis, vasos de lixo, formam planos que estão muito longe de um olhar privilegiado sobre Nova Iorque. Segundo Certeau (1998), as pinturas renascentistas representavam a cidade a partir de um olho celeste conduzido por uma pulsão gnóstica diante desse texto não redutível à univocidade, o texto urbano. O quadro em Lost book found vai mais embaixo, onde atuam os praticantes ordinários da cidade. E o filme cede a esses inúmeros caminhos possíveis desenhados por tantos outros habitantes, num ensaio seduzido pelo desejo de perder-se no meio da cidade-labirinto.

Ao contrário de Lost book found, em que o investimento nos travellings promove uma perambulação pela metrópole, os planos fixos em boa parte de News from home (à exceção de algumas poucas panorâmicas no decorrer do ensaio, ou dos travellings que remetem ao progressivo movimento de partida da personagem de Nova Iorque para a Bélgica) transmitem a impressão de que estamos lidando com uma observadora estática que registra as imagens dos transeuntes.

Em muitos planos de News from home, o descentramento do olhar promovido pela valorização da profundidade de campo, ampliando as possibilidades da perspetiva em detrimento das restrições estabelecidas por um olho central, em vez de encenar, "a ausência do sujeito" faz prevalecer a elaboração de uma subjetividade opaca por meio de uma estrutura fílmica anti-revelatória que reforça os limites do quadro. Se a mãe de Chantal anseia por respostas plenas às suas cartas, a cineasta responde com os vazios da indeterminação da narrativa do filme que parece aberta a tantas outras experiências que fraturam o ensaio. Numa sequência, a narradora lê uma carta em que a mãe pergunta sobre como estava indo o trabalho da filha num restaurante. O ensaio apresenta planos de diversos estabelecimentos a partir da janela, com o efeito de superposição de quadros reforçando um distanciamento, até que a sequência termina com a imagem de um balcão vazio à noite, numa lanchonete fechada.

Como afirma Fredric Jameson (1995), no modo impessoal como Chantal Akerman mapeia a cidade de Nova Iorque não reside um aniquilamento da subjetividade, mas outra forma de sujeito.

(...) o sujeito individual parece desaparecer atrás da coletividade sitiada que, assim, fala com ainda mais ressonância (de modo que todas as suas expressões pessoais são ao mesmo tempo políticas). Mas essa é uma concepção 
de subversão estética bastante diferente daquela da quebra das formas e dá conta de uma das características primordiais da situação pós-moderna, que por muito tempo confundimos com a morte ou desaparecimento do sujeito, mas que se mostrou ser a coletivização intensificada e a subordinação de todos os rebeldes solitários ou mônadas isoladas em novas formas de coesão e afirmação de grupo (grifo nosso). (Jameson, 1995: 178).

Akerman abre mão de um olhar unívoco e de voltar-se para si mesma, e prefere narrar a experiência a partir do mundo exterior, observando atentamente os personagens com os quais a câmera cruza, personagens que muitas vezes lhe devolvem o olhar. Segundo Jacques Aumont (1993), todo enquadramento supõe uma relação entre um olho fictício e um conjunto de objetos organizado num cenário. Enquadrar é criar centros visuais, sendo o centro absoluto o olho fictício do espectador. Akerman rompe com esse "olhar privilegiado" ao apresentar imagens entre o mecanicismo do quadro cinematográfico e a subjetividade do olhar.

Em News from home, a rigidez da moldura, promovida pela fixidez do plano, a frontalidade, as panorâmicas enviesadas, os travellings feitos a partir de trens e automóveis que jamais demonstram uma personalização do olhar e, por fim, o uso recorrente do quadro dentro do quadro são alguns elementos que reforçam os limites da janela cinematográfica e se afastam de efeitos de identificação. Não olhamos para o mundo a partir de um olho central, pois o enquadramento apresenta uma abertura para as múltiplas possibilidades do olhar através da profundidade de campo.

Em imagens como a sequência em que a câmera permanece fixa entre as colunas de uma estação de metrô, por onde passam diversos passageiros que aguardam o metrô chegar, vemos uma multiplicação de quadros a partir das relações entre figura e fundo, entre os personagens que percorrem o espaço próximo à câmera, e aqueles que se deslocam no fundo do quadro. Às vezes o quadro fica vazio, ou mal conseguimos ver um determinado personagem. News from home apresenta em diversas sequências imagens segundo o princípio do desenquadramento. Segundo Jacques Aumont (2004), desenquadrar envolve os processos de esvaziar o centro da imagem e reforçar as bordas do quadro: assim, em News from home estamos sempre em confronto com os limites da imagem, somos cotejados com o fora de quadro.

Youssef Ishaghpour, a partir de uma metáfora, nos fornece uma pista sobre News from home. Em seu ensaio O fluxo e o quadro, o autor defende que há uma relação intrínseca na obra de Akerman entre a reprodução técnica e a busca pelo apagamento da subjetividade. No entanto, ao referir-se a News from home, o autor nos indica (com um questionamento) uma relação entre procedimentos estéticos austeros (especialmente no que diz respeito ao enqua- 
dramento), na transmissão da experiência, e uma forma que vincula o pessoal e o coletivo.

Não haveria com a reprodução técnica um desaparecimento da subjetividade, um sentimento inapelável de perda e de morte, uma regressão, nostálgica de um estado de dependência, de um "lar" ("home") desaparecido? E se o que ouvimos no filme, como o mais pessoal, fosse apenas a voz dessa multidão solitária que vemos no metrô? (grifo nosso). (Ishaghpour, 2010 : 32).

A montagem de News from home apresenta planos com princípios formais repetitivos que constituem uma montagem por serialização, impondo a reprodução técnica contra uma experiência contínua. Por outro lado, a duração artesanal dos longos planos exige a paciência, o tempo de espera. Planos fixos com enquadramento frontal diante de prédios da cidade, travellings laterais a partir de veículos em movimento, planos fixos diante de pessoas atravessando o semáforo, panorâmicas em estações de metrô, são alguns exemplos de planos que se repetem no decorrer do filme. Ao se afastar dos psicologismos da narrativa autobiográfica, News from home apresenta uma forma que sugere a experiência de qualquer um, de espaços quaisquer, do tempo em que nada acontece, e não a experiência de um sujeito centrado em si que revela episódios de uma trajetória coerente. News from home dá a ver a experiência através de procedimentos estilísticos que valorizam as imagens-tempo em que diversos personagens aparecem em seu cotidiano em espaços quaisquer. Uma montagem que faz sucederem espaços quaisquer para além de sentidos unívocos impostos pelos espaços reduzidos ao encadeamento de ações de uma personagem autobiográfica.

Já a montagem de Lost book found não exprime o pensamento de um sujeito. A coexistência da voz-eu do narrador-personagem com a "voz do livro perdido e sem autor", produz uma multiplicidade de vozes sobre a justaposição das imagens. Trata-se de um texto fílmico em busca do texto urbano, com uma narrativa elaborada por múltiplas vozes, tal como o texto urbano é enunciado por tantos autores, os habitantes da cidade. Além da voz do livro, outras vozes que desestabilizam a instância narrativa centrada no narrador-personagem são as vozes de megafones obtidas pelos flagrantes documentais na cidade, como na sequência com planos de vitrines e de fachadas de lojas em que diversas vozes anunciam promoções de rádios, de malas de mão, de relógios, e de liquidação numa loja que fazia queima de estoque porque estava prestes a fechar.

O ensaio como uma "forma que pensa": ${ }^{12}$ não um sujeito que expressa o pensamento em imagens cinematográficas mas, sim, através de uma monta-

12. Godard define o ensaio como "uma forma que pensa" em Histoire( $s$ ) du cinema. 
gem que se quer à maneira de um agenciamento coletivo, tal como os habitantes agem nas enunciações do texto urbano. Os habitantes são os múltiplos autores do livro-cidade em Lost book found e as relações entre a voz do livro e a voz-eu do narrador-personagem elaboram imbricações entre o indivíduo e a coletividade incrustadas na forma do filme.

São diversos trabalhadores em esquinas com seus carrinhos ou perambulando pela cidade sob os arranha-céus, e todos eles fornecem um aspecto multifacetado ao narrador personagem. Ao se interessar pelos ambulantes, alguns deles imigrantes, "uma mulher asiática", "um homem italiano", figuras à margem da sociedade capitalista americana, o narrador assume um ponto de vista que se aproxima daquele do flâneur e, assim, "o texto se configura como uma leitura da sociedade, da perspectiva rasteira, do ângulo dos de baixo: marginalizados, desprezados, desclassificados, excluídos, descartados" (Bolle, 1994: 396).

Na literatura menor, tal como definida por Deleuze e Guattari (1977), em que o universo individual é perpassado pelo político: é o flâneur de Lost book found que tem "um olhar para baixo", um interesse pelas coisas ínfimas e pelos personagens menores, marginalizados na sociedade capitalista. Já News from home se situa entre a impessoalidade da rigidez do quadro e a subjetividade da leitora das cartas, no cruzamento dos olhares entre a câmera e os personagens: quadros em que a negação da perspetiva central e a mobilidade do olhar estimulada pela profundidade de campo se afastam do ponto de vista do "sujeito que vê o mundo", desestabilizando a identidade Eu=eu da câmera através de uma narradora-personagem que se agencia com a multidão que atravessa a cidade. Eu e outro não são essências, e conhecemos a narradora-personagem através da relação que ela estabelece com a cidade e os seus personagens.

Eu é outro, ou o ex-ambulante se encontra num devir-cidade junto com os tantos autores do livro perdido. Eu é outro, ou a estrangeira que escreve sobre a sua passagem sem fatos a partir desses encontros com os personagens em Nova Iorque, para no fim partir, sempre "sem lar", à deriva.

\section{Referências bibliográficas}

Aumont, J. (1993). A imagem. Campinas: Papirus - (Coleção Ofício de Arte e Forma).

Aumont, J. (2004). O olho interminável - cinema e pintura. São Paulo: Cosaac e Naify.

Bellour, R. (2009). Entre-imágenes: Foto. Cine. Video. Buenos Aires: Colihue. 
Bergstrom, J. (2004). News from home. In C. Akerman, Autoportrait en cinéaste. Paris: Cahiers du cinema - Centre Pompidou.

Bolle, W. (1994). Fisionogmia da metrópole moderna - representação da história em Walter Benjamin. São Paulo: Edusp.

Certeau, M. (1998). A invenção do cotidiano: artes de fazer. Petrópolis: Editora Vozes.

Chion, M. (1999). The voice in cinema. Nova Iorque: Columbia University Press.

Comolli, J.-L. (2008). Ver e poder - a inocência perdida: cinema, televisão, ficção, documentário. Belo Horizonte: Editora UFMG.

Deleuze, G. (2005). A imagem-tempo. São Paulo: Editora Brasiliense.

Deleuze, G. (1983). A imagem-movimento. São Paulo: Editora Brasiliense.

Deleuze, G. \& Pernet, C. (1998). Diálogos. São Paulo: Editora Escuta.

Deleuze, G. \& Guattari, F. (1977). Kafka - por uma literatura menor. Rio de Janeiro: Imago editora.

De Man, P. (1979). Autobiography as de-facement. Comparative Literature, 94(5). Baltimore: John Hopkins University Press. Disponível em http://www.jstor.org/discover/10.2307/2906560?uid=2\&uid=4\&sid=211 03476705213

Ishaghpour, Y. (2010). O fluxo e o quadro. Revista Devires - Cinema e Humanidades, 7(1): 24-35. Belo Horizonte.

Jameson, F. (1999). As marcas do visível. Rio de Janeiro: Graal.

Lejeune, P. (2008). O pacto autobiográfico - de Rousseau à internet. Belo Horizonte: Editora UFMG.

Marguiles, I. (1996). Nothing happens. Chantal Akerman's hyperrealist everyday. Durham and London: Duke University Press.

Mesquita, C. (2006). Lost book found: uma cidade ao rés do chão. Revista Devires - Cinema e Humanidades, 3(1): 132-149. Belo Horizonte: Editora UFMG.

Neyrat, C. (2004). L'essai à la limite de la terre et de l'eau. In M. Gagnebin \& S. Liandrat-Aguigues (org.). L'essai et le cinéma. Paris: Ed. Champ Vallon.

Pasolini, P.P. (1982). Empirismo hereje. Lisboa: Assírio e Alvim.

Ramos, F.P. (2008). Mas afinal... o que é mesmo documentário?. São Paulo: Editora Senac São Paulo. 
Starobinski, J. (2011). É possível definir o ensaio?. Revista Remate de Males. Campinas.

\section{Filmografia}

News from home (1977), Chantal Akerman.

Lost book found (1996), Jem Cohen. 